\title{
雑貨貨物の岸壁上載荷重の設計値に関する研究 \\ DESIGN VALUES OF SURCHARGE FOR GENERAL CARGO BASED ON FIELD OBSERVATION
}

\author{
森屋陽一 ${ }^{1} \cdot$ 山本修司 ${ }^{1}$ \\ Yoichi MORIYA and Shuji YAMAMOTO \\ ${ }^{1}$ 正会員 工博 国土技術政策総合研究所 港湾研究部（于239-0826 神奈川県横須賀市長瀬3-1-1）
}

\begin{abstract}
In the design of port structures, it is important to decide actions rationally. When designing port structures by the reliability design method corresponding to international standards, it is necessary to evaluate probability distributions of actions. Moreover, in order to determine rationally the partial factors used for the partial factor method, the probability distribution of actions is required.

In this research, we took the focus to the surcharge by cargos on a quaywall. Field observation about the surcharge was performed in the berth for general cargos of the Yokohama port in Japan. The observation using a digital video camera was conducted. Analysis was performed based on the video image and the cargo size and weight data offered from some ship companies. The probability distribution of surcharge was evaluated. The design values of surcharge at normal time and earthquake time were estimated using by the probability distribution.
\end{abstract}

Key Words : design value, surcharge, general cargo, field observation, partial factor

\section{1. はじめに}

港湾構造物の設計において，合理的に荷重を決定 することは重要である．合理的に荷重を決定するた めには，荷重の確率変動を考慮することが必要であ る. 国際規格（ISO2394）では，設計の照査法とし て部分係数法を採用しており, 部分係数に荷重の確 率特性が反映されている.

しかしながら, 現在の日本の港湾構造物の設計法 は, 安全率に基づく方法あるいは許容応力度法が採 用されている. また，設計に用いるすべての荷重が 合理的に決められているわけではない, 今後, 国際 規格との整合性を考慮し, 部分係数法により港湾構 造物を設計していくためには, 荷重の確率分布を用 いて部分係数や組み合わせ係数を算定し, 合理的に 荷重の設計値を決める必要がある.

現在，日本における港湾構造物の設計においては， 岸壁の上載荷重の設計值は, 常時 $10 \sim 30 \mathrm{kN} / \mathrm{m}^{2}$, 地 震時は常時の $1 / 2$ としている1). しかしながら，10〜 $30 \mathrm{kN} / \mathrm{m}^{2}$ という值は経験的に決められたものであり, 地震時は常時の $1 / 2$ にするというのも明確な根拠が ない。

本研究では, 従来, 経験的に決められた值を用い て設計を行っている岸壁上に作用する雑貨貨物の上
載荷重を検討対象とした。 そして，横浜港の山下埠 頭7号バースにおいて上載荷重に関するビデオ観測 と資料収集を行い，その結果を整理することにより 上載荷重の経時変化を評価し確率分布関数の算定を 行った．また，算定した確率分布関数から，部分係 数や組み合わせ係数を算定し, 常時および地震時の 上載荷重の設計值の評価を行った.

設計法の国際整合性を考えた場合，対象となる国 際規格はISO2394である.しかしながら，構造物の 設計法においては，ウィーン協定により Eurocodes が国際規格の原案になることが定められている.

よって, 本研究では, ISO2394のみならずEurocode1 も参照して設計值の評価を行った. ISO2394および Eurocode1は, 設計法として部分係数法を採用して いる. 以下に, ISO2394およびEurocode1による常時 および地震時の荷重の設計値の評価方法を示す2), 3). 常時の荷重はその特性値に荷重係数（荷重に対す る部分係数）を乗じることにより，設計值になる. 常時の荷重の設計値 $Q_{d}$ は,

$$
Q_{d}=\gamma_{Q} Q_{k}
$$

と表される. ここで， $\gamma_{Q}$ は荷重係数， $Q_{k}$ は荷重の 特性値である. 上載荷重は変動荷重であるため, そ の特性值は, 対象とする構造物の供用期間を 50 年で あると考えると, 変動分 (非ゼロ) のデー夕に対す 
る確率分布の $98 \%$ フラクタル值をとる. つまり,

$$
Q_{k}=F_{Q}{ }^{-1}(0.98)
$$

である.ここで, $F_{Q}$ は非ゼロの荷重のデー夕に対 する確率分布関数であり, 上付の-1はその逆関数で あることを意味する.

荷重係数は,

$$
\gamma_{Q}=F_{Q}{ }^{-1}\{\phi(\alpha \cdot \beta)\} / Q_{k}
$$

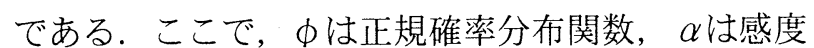
係数である. 感度係数は. その荷重の構造物への影 響度合いであり，FORMなどの信頼性解析により評 価することができる2). しかしながら，上載荷重の 感度係数は, 岸壁の構造形式などにより值が異なる ため,ここではISO2394およびEurocode 1に示され ている標準値を用いる. 主たる荷重に対する感度係 数の標準值は-0.7, 従たる荷重に対する感度係数の 標準値は-0.28である.ただし，対象とする荷重が 主たる荷重か従たる荷重かは, 設計者などが判断す る必要がある。 また， $\beta$ は構造物の目標信頼性指標 であり，破壊確率を $10^{-4}$ 程度に想定した場合の標準 值は3.8 となる。(3)式に(2)式および $\alpha, \beta$ の標準值 を代入すると， $\alpha=-0.7$ の場合，

$$
\begin{aligned}
& \gamma_{Q}=F_{Q}{ }^{-1}(0.9961) / F_{Q}{ }^{-1}(0.98) \\
& \alpha=-0.28 \text { の場合, } \\
& \gamma_{Q}=F_{Q}{ }^{-1}(0.9503) / F_{Q}{ }^{-1}(0.98)
\end{aligned}
$$

となる.

地震時の荷重の設計値 $Q_{E d}$ は,

$$
Q_{E d}=\Psi_{2} Q_{k}
$$

と表される．ここで， $\Psi_{2}$ は準永続值に対する組み 合わせ係数である.

組み合わせ係数は,

$$
\Psi_{2}=F_{Q}{ }^{-1}(1-\eta / q) / Q_{k}
$$

により算定できる.ここで，qは荷重が非ゼロであ る確率， $\eta$ は全時間に対して荷重が $Q_{E d}$ を越えてい

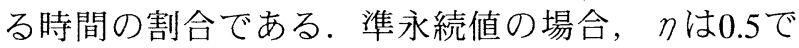
ある.

\section{2. 現地観測}

\section{（1）観測期間・場所}

エプロン上に載荷される上載荷重の経時変化を評 価するために，2000年9月18日〜2000年11月20日の 約2ヶ月間，横浜港において現地観測を行った。本 研究では, 雑貨貨物を対象にしたので, 横浜港の中 で雑貨貨物の取扱量が多く, 観測におけるカメラの 電源や設置場所などが確保できる山下埠頭7号岸壁 において観測を行った.

横浜港の山下埠頭7号岸壁は, 重機を主要取り扱 い貨物としており, 年間の貨物取扱量が約 12 万トン, 月に平均して 5 隻程度の貨物船が着岸する。 また, バース長 $180 \mathrm{~m}$, バース幅 $20 \mathrm{~m}$, 水深 $-11.2 \mathrm{~m}$, 岸壁天 端高 $+3.5 \mathrm{~m}$ の直杭式栈橋構造で, 上載荷重の設計值
は常時 $20 \mathrm{kN} / \mathrm{m}^{2}$, 地震時 $10 \mathrm{kN} / \mathrm{m}^{2}$ である.

\section{（2）観測方法}

現地調査は, バース上の貨物のビデオ観測および 参考資料の収集により行った. バース上の貨物のビ デオ観測には，デジタルビデオカメラを使用した. ビデオカメラに遠隔操作および画像転送機器を接続 し, 携带電話を経由して, 他所のパソコンにてビデ オカメラの操作および撮影した静止画像の受信を 行った. 図一1は, 観測システムの構成の模式図で ある. ビデオカメラ, 遠隔操作および画像転送機器 はアウトドア用のドームに入れ，バースが見渡せる 鉄塔の高さ $14.9 \mathrm{~m}$ の位置に設置した. ビデオカメラ による撮影時間間隔は, 岸壁上で貨物の動きが活発 な入船時には5分間隔, その他の日には30分間隔と した. また, 調查期間中は毎日午前 6 時〜午後 5 時の 間撮影を行った.

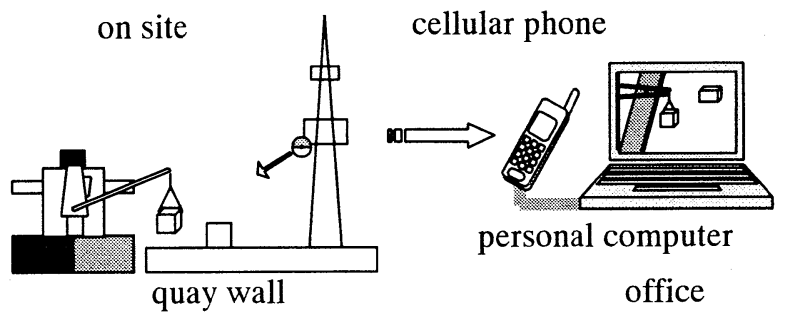

図-1＼cjkstart観測システムの構成の模式図

収集した資料は，横浜市港湾局から提供しても らった入船スケジュールと貨物の積みおろしに係わ る代理店もしくは荷役会社から提供してもらった積 荷目録や荷役書類である.これら資料により，入船 日時, 入船船舶諸元, 荷役貨物の種類・寸法・重量, 船体への積み込み位置などの把握を行った。

\section{（3）観測期間中の状況}

観測期間中，対象バースには10船が入船した。船 舶への荷役作業および上屋からの搬出入作業は, 平 日のおよそ午前 8 時過ぎから午後 5 時にかけて行われ ており, 夜間作業および土日祝日作業は行われてい なかった。

エプロン上で，貨物はほとんど海側に置かれ，上 屋側は主に交通路として利用されていた。 また，船 舶が着いていないときも, 荷さばきにエプロン上を 利用していたが，トラックやコンテナへの積み込み 作業は海側で行われていた。 上屋側は，主として雨 天時や海側に荷役貨物が積まれている場合に，上屋 への荷物の搬出入に利用されていた.

岸壁上での取り扱い貨物は, 主に重機, 車両, 木 材, 雑貨物などであった. 重機や車両などの貨物は, 船舶の積み込み作業前日に岸壁上に運び込まれ, 夜 間も置いたままになっている場合もあった。また, 早朝から輸送車両が岸壁内に停車し, 荷役・搬出作 業を待つこともあった。 


\section{3．現地観測結果の解析}

\section{（1）上載荷重の経時変化}

図ー2に示すように，岸壁のエプロン部分 $(200 \mathrm{~m}$ $\times 18 \mathrm{~m} ） を 20 \mathrm{~m} \times 9 \mathrm{~m}$ の 20 領域に等分割し，それぞれ にNo.1〜No.20の領域番号を付けた，収集した参考 資料とビデオ画像から，エプロン上の貨物の置かれ た領域, 重量, 接地面積を評価した.

観測結果の上載荷重は，貨物の接地面積で除す ことにより，接地面積あたりの荷重（圧力）とし て整理した. 貨物が2つ以上の領域にまたがって置 かれている場合には，面積比に基づいて荷重を配分 した.

夜間の載荷状況については，エプロン上がライト アップされていないことから，ビデオ画像による評 価ができないため，午後5時と翌朝の午前6時のデー タから推測した. 移動中のトラックやフォークリフ トなどの活荷重については, 調査対象外とした。

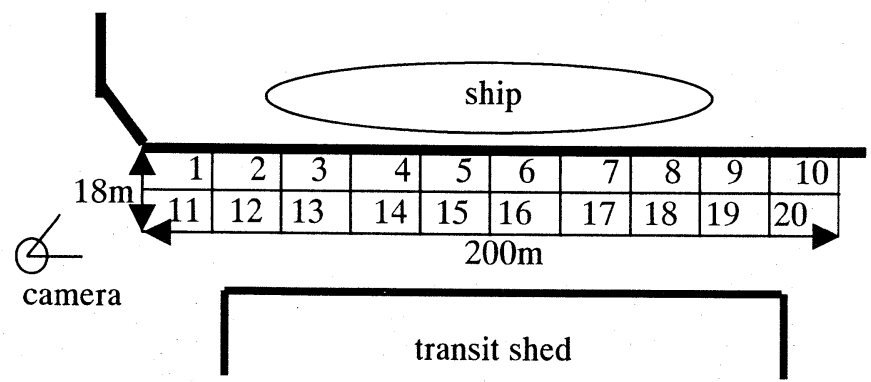

図-2 領域分け（領域番号）の模式図

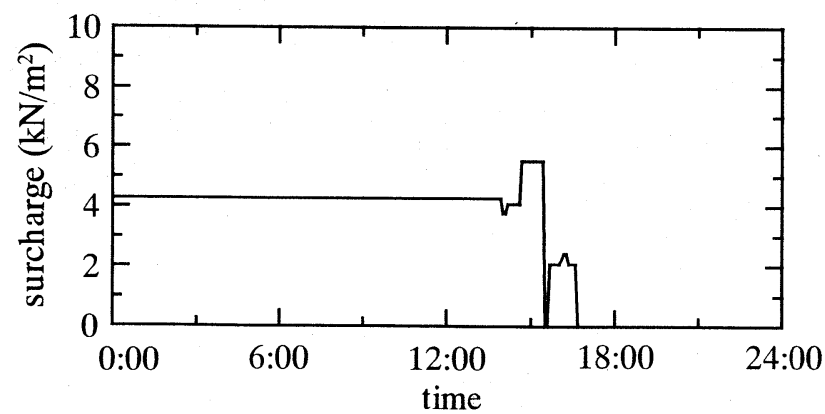

(a) 領域No.3

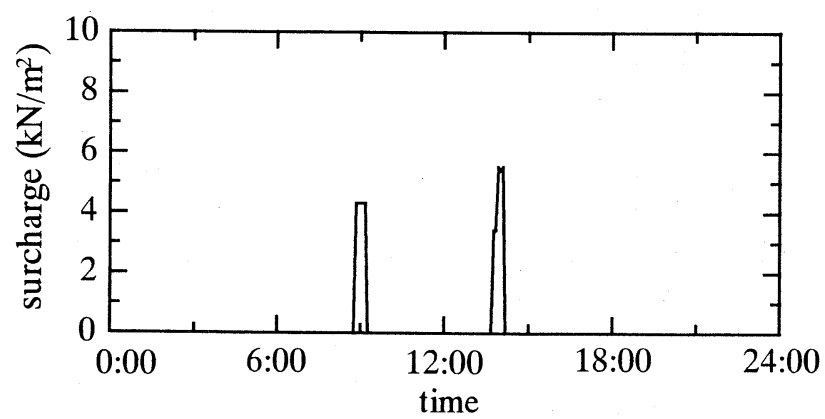

(b) 領域No.13

図一－3 単位面積あたりの上載荷重の経時変化 (9月28日)
図一3は，9月28日の領域No.3とNo.13の上載荷重 の経時変化である。本研究では，同様の時系列が 観測期間分，領域分得られた.

\section{（2）上載荷重の空間分布}

図ー4に単位時間あたりの上載荷重の空間分布を 示す。横軸は, 図一2で示した領域の位置を表し， 縦軸は，単位時間あたりの上載荷重であり，領域 別に評価した上載荷重の経時変化の時系列の総和 を取り，観測時間で除したものである。

No.11を除けば，貨物は，ほとんど海側に置かれ ていたてとがわかる。No.1およびNo.11付近は， No.1を交通路として使っていた場合が多く，上屋 側であるNo.11には，空のコンテナなどが数段積ま れていた。 そのために，No.11は上屋側の他の領域

（No.12〜No.20）に比べて大きな值を示している. また，バース方向に着目すると，単位時間あた りの上載荷重の空間分布は，主として，船体上の クレーンの位置になるNo.5〜 7, 通路となるNo.1で 小さな值になっている。しかしながら，単位時間 あたりの上載荷重は，全体的に見て，バース方向 には変化は小さい。

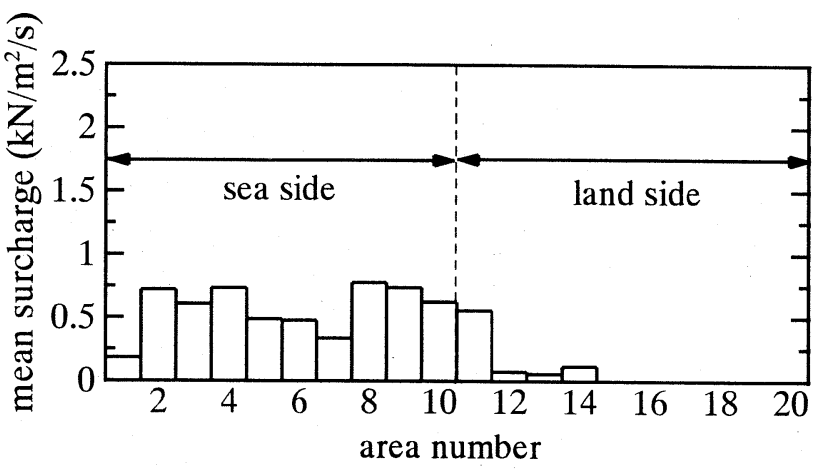

図-4 単位時間あたりの上載荷重の空間分布

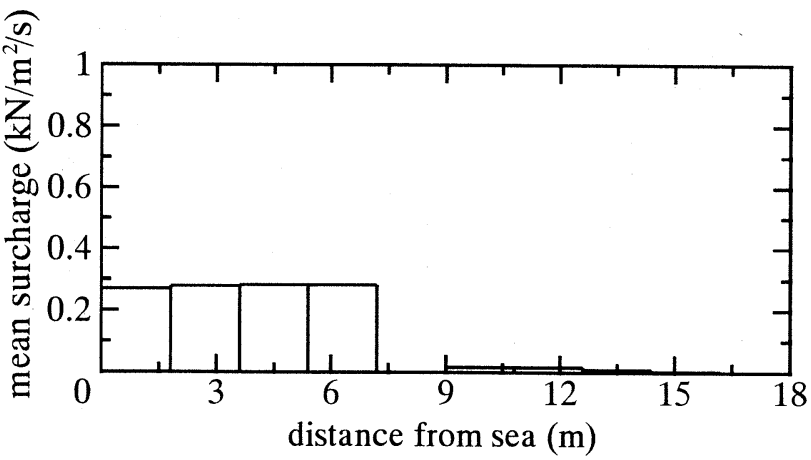

図 -5 海一上屋方向の単位時間あたりの上載荷重の空 間分布（9月28日）

続いて，海一上屋方向の上載荷重の分布特性を 細かく調べるために，領域を細分して上載荷重を 評価した。領域の分割は，図一2に示したNo.3と No.13を合わせた領域を海一上屋方向に $20 \mathrm{~m} \times 1.8 \mathrm{~m}$ の10等分とした。図一 5 は海一上屋方向の単位時間 あたりの上載荷重の空間分布である。用いたデー 夕は，9月28日の1日（24時間）分である。図の横 
軸は海からの距離である。海側から5領域目以降は 荷重が小さくなっており，使われているのは海側 の7.2m程度であることがわかる.

\section{（3）上載荷重の確率分布}

港湾構造物の設計は, 通常, 設計条件, 地盤条 件などが同一の範囲では同一の構造とし, 構造物 の単位幅に対して，ての安定性の検討が行われる. 実際の上載荷重は, 図ー4および図一5で示したよ うに，空間的に一様ではない。しかしながら，設 計において，上載荷重は，考えている断面のエプ ロン上に一様に分布しているものとして扱われる. そこで, 設計に用いるための上載荷重の確率特性 の検討にあたり，以下の仮定を行った。

(1) 設定した各観測領域（No.1〜No.20）における 上載荷重の載荷頻度は一様である（空間的一様 性)

(2) 各領域に置いて観測されたデー夕は定常であ る（時間的一様性）
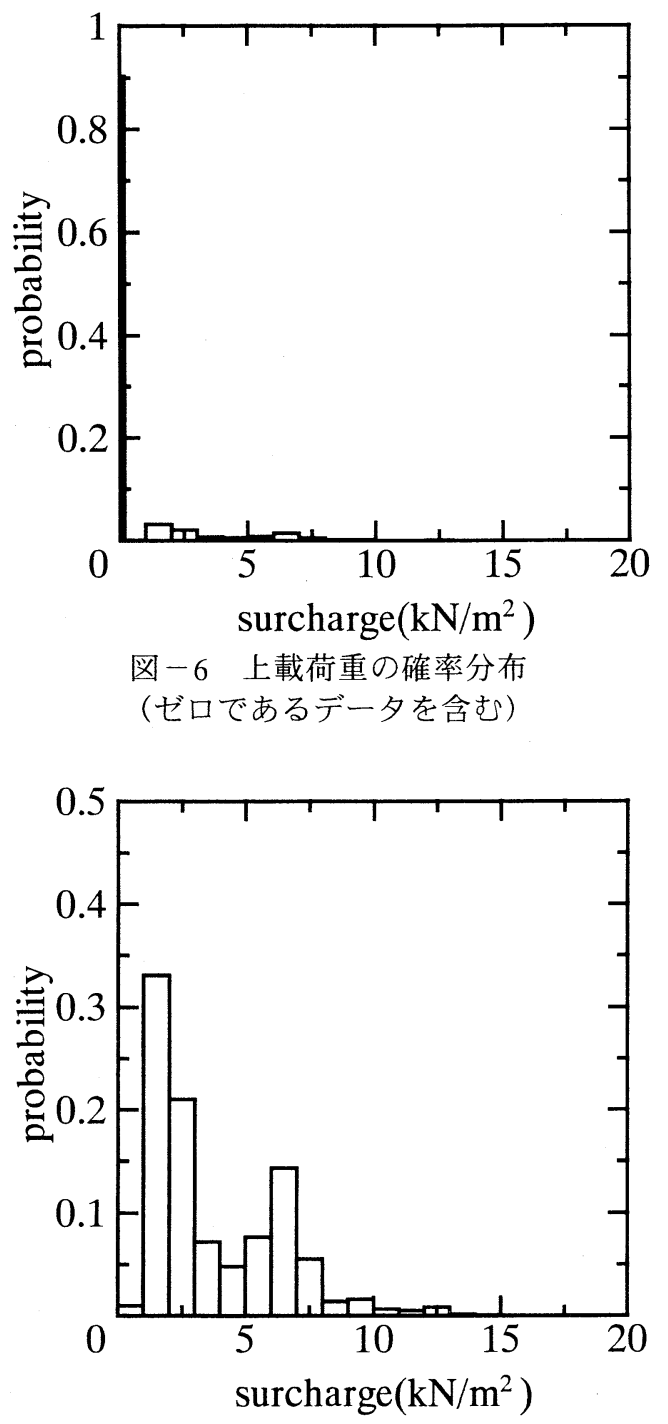

図-7 上載荷重の確率分布 (ゼロであるデータはカット)
前述の仮定により, 領域毎に評価した上載荷重 の值を20領域分すべてカウントし，エプロン上全 体としての上載荷重の確率分布を算定した。 また, 上載荷重がゼロのデータはゼロのデータのみで確 率を算定している。図一6にゼロであるデー夕も含 めたエプロン上の上載荷重の確率密度分布を示し, 図一7にゼロであるデータをカットしたエプロン上 の上載荷重の確率密度分布を示す。

上載荷重の確率の $90.3 \%$ はゼロであり, 今回の観 測および整理方法では, エプロン上に上載荷重が作 用していない時間が，全体の約9割を占めるという 結果になる。 上載荷重の最大值は $26.2 \mathrm{kN} / \mathrm{m}^{2}$ であっ たが，そのランクの確率はゼロをカットして整理し た場合でも0.0062 と非常に小さく, ほとんどのデー 夕は $10 \mathrm{kN} / \mathrm{m}^{2}$ 以下となっている。.また, 上載荷重の 確率分布は，2山型になっている。これは，この バースで扱われている貨物が平均 $7 \mathrm{kN} / \mathrm{m}^{2}$ 程度の重 いもの（重機・車両）と平均 $2 \mathrm{kN} / \mathrm{m}^{2}$ 程度の軽いも の（木材・雑貨）とに分かれるためであると考えら れる.

\section{4. 設計値の評価}

\section{（1）分布関数のあてはめ}

ゼロであるデータをカットした上載荷重の確率 分布に, 確率分布関数をあてはめ, 上載荷重の母 集団の確率分布の推定を行った.

分布関数のあてはめは，合田（1990）に従い, 最小二乗法により行った ${ }^{4)}$. あてはめを試みた分 布型は，正規分布，対数正規分布，ワイブル分布， グンベル分布である。合田（1990）では，ワイブ ル分布の母数 $k$ を $0.75,1.0,1.4,2.0$ の 種類に固定し ているが, 本研究では, さらに母数 $k$ 変化させて より適合度の高い分布型状の評価を試みた。デー

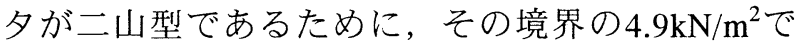
デー夕を分け，それぞれのデータについて別々に 分布型をあてはめた.

それぞれの分布型のあてはめ結果を表一1および 表一2に示す. 表中の $A$ およびBは各分布関数のパ ラメタである（合田（1990）参照）。また，あて はめ結果のグンベル分布とワイブル分布の確率密 度関数を図ー7に示した確率密度分布に重ねた結果 を図一 8 および図 -9 に示す。 $4.9 \mathrm{kN} / \mathrm{m}^{2}$ 未満, $4.9 \mathrm{kN} / \mathrm{m}^{2}$ 以上のデータ共に, ワイブル分布の相関 $R^{2}$ が最も高くなっている。しかしながら， $4.9 \mathrm{kN} / \mathrm{m}^{2}$ 以上のワイブル分布の母数 $k$ は 1 以下にな り, 分布型状がスパイク状になるため, 以下の検 討では, 次に相関係数が高いグンベル分布を用い ることとした。また，グンベル分布の分布関数を 式で表せば,

$$
F(x)=\exp \left\{-\exp \left(-\frac{x-B}{A}\right)\right\}
$$

である。ここで， $4.9 \mathrm{kN} / \mathrm{m}^{2}$ 末満， $4.9 \mathrm{kN} / \mathrm{m}^{2}$ 以上に あてはめた二つの分布型に重なる部分があるため, 
二つの分布型を数值的に加え合わせ，面積が1にな るように正規化している.

表 -1 分布型のあてはめ結果 $\left(4.9 \mathrm{kN} / \mathrm{m}^{2}\right.$ 末満 $)$

\begin{tabular}{|c|c|c|c|c|}
\hline Distribution type & $k$ & $A$ & $B$ & $R^{2}$ \\
\hline Normal & - & 0.762 & 2.257 & 0.855 \\
\hline Log-normal & - & 0.319 & 0.756 & 0.921 \\
\hline Gumbel & - & 0.623 & 1.897 & 0.943 \\
\hline Weibull & 1.3 & 1.126 & 1.216 & 0.960 \\
\hline
\end{tabular}

表 -2 分布型のあてはめ結果 $\left(4.9 \mathrm{kN} / \mathrm{m}^{2}\right.$ 以上)

\begin{tabular}{|c|c|c|c|c|}
\hline Distribution type & $k$ & $A$ & $B$ & $R^{2}$ \\
\hline Normal & - & 1.606 & 6.798 & 0.728 \\
\hline Log-normal & - & 0.210 & 1.888 & 0.879 \\
\hline Gumbel & - & 1.383 & 6.000 & 0.888 \\
\hline Weibull & 0.81 & 1.315 & 5.321 & 0.952 \\
\hline
\end{tabular}

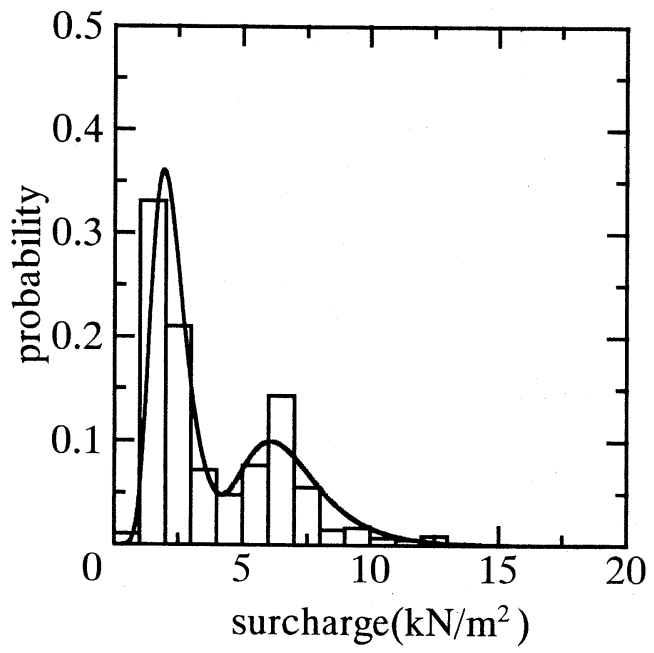

図-8 グンベル分布のあてはめ結果

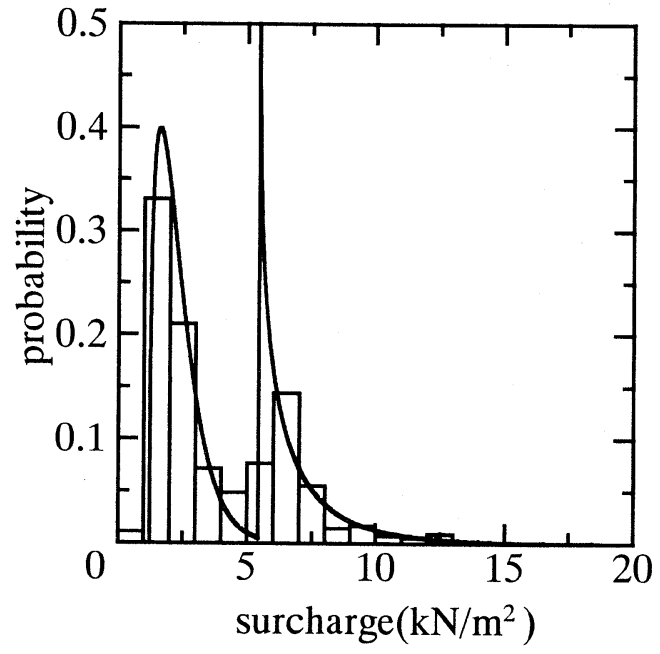

図-9 ワイブル分布のあてはめ結果

\section{（2）常時および地震時の設計値の評価}

(1)〜(7)式で示したISO2394およびEurocode1の方 法を用いて, 評価した上載荷重の確率分布関数に より, 特性值, 荷重係数, 組み合わせ係数を算定 し, 常時および地震時の設計值の評価を行った。

特性值は, 構造物の供用期間を 50 年と考えると, 確率分布の $98 \%$ フラクタル值を用いることになる. (2)式より, 上載荷重の特性值々 $10.0 \mathrm{kN} / \mathrm{m}^{2}$ となる.

上載荷重の設計值は，(4)式および(5)式より荷重 係数を評価し，それを(1)式に用いることにより評 価できる，構造物の破壊確率を $10^{-4}$ とし，上載荷重 を主たる荷重と考えると荷重係数は1.23, 常時の設 計值は $12.3 \mathrm{kN} / \mathrm{m}^{2}$ となり, 上載荷重を従たる荷重と 考えると荷重係数は 0.70 , 常時の設計值は $7.0 \mathrm{kN} / \mathrm{m}^{2}$ となる。

次に, 地震時の組み合わせ係数を，(6)式および (7)式より評価する. 上載荷重が非ゼロである確率 $q$ は0.097であり（図一6を参照）， $\eta$ の準永続值に対

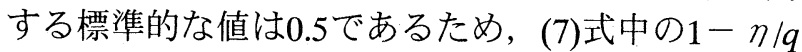
が負になり(7)式の計算はできない。よって，組み 合わせ係数 $\Psi_{2}$ は 0.0 となり，(6)式より地震時の上載 荷重の設計値は $0.0 \mathrm{kN} / \mathrm{m}^{2}$ となる.

\section{（3）組み合わせ係数に関する検討}

観測結果から地震時の上載荷重の設計值は $0.0 \mathrm{kN} / \mathrm{m}^{2}$ となった。この理由は，上述したが，準永 続值に対する組み合わせ係数である $\Psi$, の評価に際 して，(7)式中の上載荷重が非ゼロである確率 $q$ が $\eta$ （=0.5）より大きくなるためである.

上載荷重が非ゼロである確率 $q$ は，バースの使用 頻度により異なる．そこで，今回の観測により得ら れた上載荷重の確率分布関数を用いて(7)式中の $q$ を $0.0 \sim 1.0$ と変化させ， $\Psi_{2}$ の評価を行った.

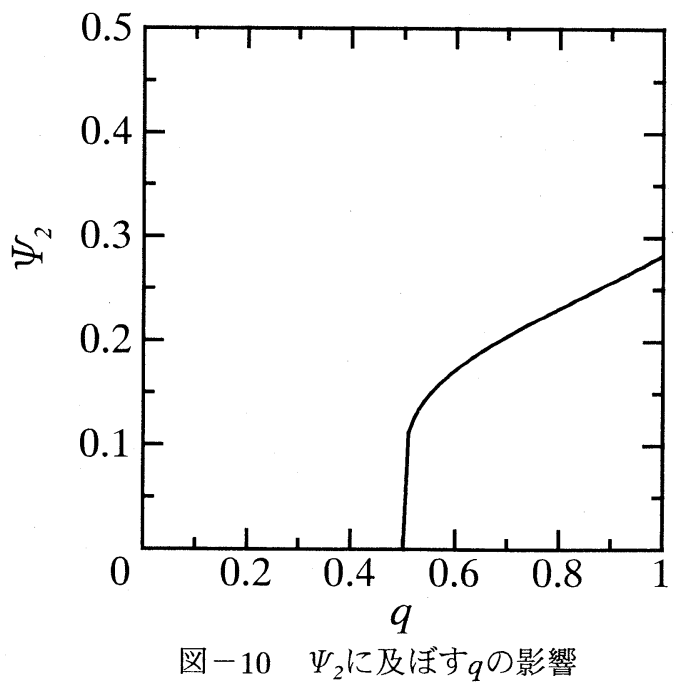

図ー10は $\Psi_{2}$ に及ぼす $q$ の影響を示したものである. 当然, $q$ が0.5より小さければ, (6)式より $\Psi_{2}$ の評価

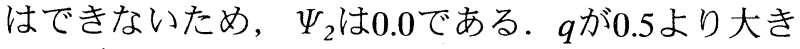
ければ， $\Psi_{2}$ の評価は可能であり，qが大きくなると， 
$\Psi_{2}$ も大きくなる．しかし，上載荷重が常に岸壁に

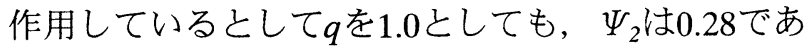
る.よって，今回の観測結果において，上載荷重が 常に岸壁に作用していると考えたとしても，地震時 の上載荷重の設計值は $2.8 \mathrm{kN} / \mathrm{m}^{2}$ である.

\section{5.おわりに}

本研究では, 雑貨貨物を対象にした横浜港におけ る現地調査により，岸壁上に作用する上載荷重の確 率分布を評価した。次いで, ISO2394 および Eurocode1に従い, 上載荷重の特性值, 荷重係数, 組み合わせ係数を算定し，常時および地震時の設計 值を評価した。

得られた結論は,

(1) 上載荷重は二山型の分布型になる.

(2) グンベル分布を重ね合わせることにより確率分 布を表すことが可能である.

(3) 上載荷重を主たる荷重と考えた場合の常時の設 計值は $12.3 \mathrm{kN} / \mathrm{m}^{2}$ となり, 従たる荷重と考えた場合 の常時の設計值は $7.0 \mathrm{kN} / \mathrm{m}^{2}$ となった. また, 地震時 の上載荷重の設計值は $0.0 \mathrm{kN} / \mathrm{m}^{2}$ となった.
ただし，この結論は, 雑貨貨物を対象にした横浜 港山下埠頭の 1 バースでの観測結果に基づくもので ある.

今後の課題として, 多地点での観測を行い上載荷 重の確率分布の信頼性を向上させると共に, 雑貨貨 物だけでなく，ばら荷やコンテナなどを対象にした 検討を行っていく必要がある.

最後に, 本研究の現地観測およびデータの解析に おいて，横浜市港湾局の高木勇一氏，（株）日本海 洋科学の津金正典氏と佐々木伸宏氏に協力していた だいた。ここに記して感謝の意を表する.

\section{参考文献}

1） 日本港湾協会 : 港湾の技術上の基準・同解説, 1998.

2) ISO : ISO2394, General principles on reliability for structures, 1998.

3) JCSS : Background documentation Eurocode 1 ( ENV1991) Part 1, Basis of Design, 1996.

4) 合田良實: 港湾構造物の耐波設計, 鹿島出版 会，1990。 